\title{
About W.E.B.B.: Working Educator's Bulletin Board
}

By Patricia O’Brien Libutti and Kimberly Kelley

EBSS develops its annual program on the Web

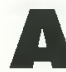

CRL's Education and Behavioral Sciences Section (EBSS) has initiated an outreach component as part of program planning: W.E.B.B., the Working Educator's Bulletin Board (http://www.umuc.edu/ kelley). W.E.B.B.'s purpose is to link the many interested librarians who will not be able to attend the EBSS program in New York at the ALA Annual Conference, and to provide a preprogram resource to prepare for the actual event. The EBSS Program Planning Committee, chaired by Kim Kelley, developed the site using regional resources selected for connection to the program topic, as well as for perspectives on diverse library leadership applications. The site's components and contents are described below.

\section{EBSS program description}

Strategic Academic Partnersbips: Leading

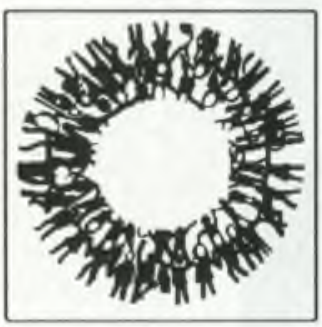

the Development

of Interactive Learning Environments. July 7 , $1996,9: 00$ a.m.12:00 p.m. The program is intended to provide the participant with ways to see leadership applications regardless of their position in the library. Breakout sessions will follow four speakers, each link- ing to the topic with specific partnership scenarios.

\section{Biographies: Program presenters and facilitators}

Speakers include: Susan Blandy, Hudson Valley Community College (faculty link), David Carr, SCILS, Rutgers University (mentoring link), Ree DeDonato, (interactive environment link), and Tom McFadden, University of Northern Arizona (reality links).

\section{Bibliographies: Topic background}

Carr, D. "A Short List of Favorites." Course.

Cherepon, L. "Creating Strategic Alliances in Higher Education." ACRL/NY Symposium, 1994. "Finding Common Ground: Creating a Library of the Future Without Diminishing the Library of the Past." Harvard College Library, March 30-31, 1996: listing of papers, forthcoming in Proceedings.

Hicks, M. "Librarians As Forces in Instructional Design/Learning Environments." Prepared for W.E.B.B.

Kaplan, A. "Librarians As Leaders in CERL News.

An Annotated Bibliography." Prepared for W.E.B.B.

Libutti, P., and V. Spain. "Educating Educators As Leaders: Implications for Librarians." Prepared for W.E.B.B.; available at program.

Lopatin, L., and P. Libutti. "Libraries in Transition: Learning \& Communication in an Electronic Environment." ACRL/NY Symposium, 1995. Ostrow, R. "Library Culture \& Technology." Dissertation bibliography.

Spain, V. "Internet and Instruction: An Annotated Bibliography." ACRL/NY event.

Patricia O'Brien Libutti is education subject specialist at Fordham University and chair of EBSS, Libutti@ mary fordham.edu; Kimberly Kelley is director of the Office of Library Services at the University of Maryland University College and chair of the EBSS Annual Conference Program Committee, Kelley@nova.umuc.edu. Kelley designed W.E.B.B. 


\section{Course and instructional materials}

This section includes course syllabi, instructional sheets, assignment construction tips, and visuals. The materials were selected in recognition of exemplary instructional design.

Blandy, S. "Research and Bibliography: A Syllabus." State University of New York: HVCC.

Carr, D. "Information Resources in the Humanities: A Syllabus." Rutgers.

Carroll-Mathes, P. "Collaborative Information Literacy: A Syllabus." State University of New York: Ulster Community College. Awarded ACRL/IS Innovation in Instruction Award.

Jacobson, T. "User Education: A Syllabus." State University of New York at Albany: Library Studies.

Wasserman, R. "The Study of Literature: A Syllabus." Fordham University at Lincoln Center.

\section{Librarian lore: Anecdotes from the field}

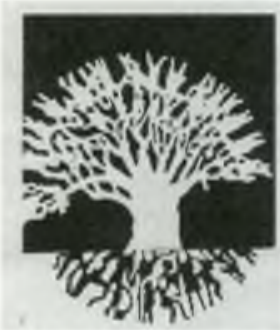

This segment invites you to be a participant-add your ideas and experience to the collection. This "story" approach is seen in the ACRL/EBSS 1995 publication Teaching Information \& Retrieval Skills to Educators: $A$ Casebook of Applications (Patricia Libutti and Bonnie Gratch, eds.).

Blandy, S. "Overheard at the Kitchen Table: The Librarian's Image." Reprinted with permission. New York: ALSL Newsletter, 1995.

Gratch, B. "California Association of Research Libraries: Notes: Ideas \& Stories from the Field." Conference literature, 1996.

Elkins, E. "New Year's Resolutions." Reprint. New York: ALSL Newsletter, 1996.

\section{Guide to product assessment at ALA vendor's exhibit}

We are in a high-stimuli, rapid-paced information environment at the exhibition, designed to get our attention. Information retrieval and evaluation skills are essential as a basis for responsible product assessment. Included here are some points to consider as you prepare to be a conduit of "New Product News" to your library.
Karen, L. "Tip Sheet: What to Ask and What to Try at the Vendor's Booth." Westchester Community College, Valhalla, New York.

Libbey, G. "Tip Sheet: At the Exhibit: Getting the Most Out of It." University of Detroit, Michigan.

LoSchiavo, L. "Report to Library Staff: Matching Products to Library Needs." Quinn Library, Fordham University at Lincoln Center, New York.

\section{Debate and discussion}

Included here are provoking points of view for reality-based planning

McFadden. T. "Just Say No to the Internet." Text of speech given.

Carr, D. "Questions of the Course." Student questions collated from spring 1995.

\section{New York, New York: Cool spots in a hot town}

Since ALA Annual occurs over a hot holiday weekend, this section provides sites to tour New York ahead of time (virtually). Both commercial and education sites give links to a Hot Town. Also included is David Carr's recipe for iced tea, which can be brewed by anyone browsing W.E.B.B.

\section{Notes on underlying issues}

W.E.B.B. is representative of the synergy among many librarians, whose ideas, in concert, com-

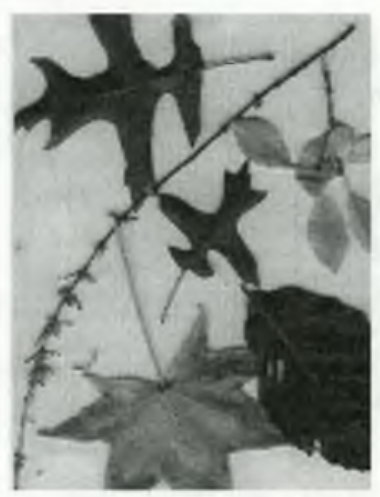
pose a Virtual Learning Environment. EBSS committee members were concerned with both making information accessible and acknowl edging intellectual origins. You will see "Reproduction with this footnote of attribution included permitted by the author(s)" on many of the contributions.

We expect that the EBSS Program at the ALA Annual Conference in New York will extend W.E.B.B., and we encourage you to contact either of the authors with your suggestions or comments. 